have been given even more fully with figures in this Magazine for December, 1888, by Dr. Gustav Lindström (p. 532), and subsequently in March last by Mr. A. H. Foord (p. 121).-Introduction, pp. xvii and xviii.

Besides giving a "Table of the Nautiloidea," prepared with a view to show the groups into which the species described by the author have been subdivided, Mr. Foord has also provided an excellent quarto table of the classification of the Lower Palæozoic rocks of Europe and North America, giving as nearly as possible the corresponding horizons for Britain, Scandinavia, Russia, Bohemia, France, and North America. This in itself forms a most valuable boon to the seientific worker, and will prove highly acceptable for other groups besides the Cephalopoda.

We are greatly indebted to Mr. Foord for this his first instalment of a Catalogue of the Fossil Cephalopoda in the British Museum, and we trust he will not rest until he has completed this great work, and we, for our part, will continue to pray for its speedy delivery by Messrs. Taylor and Francis, equally well executed in its entire form as is the volume now before us.

II.-Catalogue of the Fossil Fishes in the British Museum (Natural History). Part I. containing the ElasmoBranchil. By Arthur SMith Woodward, F.G.S., F.Z.S. 8vo. pp. xlvii. and 474, with 17 Plates and 15 Woodcuts. (London, Trübner \& Co., Printed by order of the Trustees.)

TTNDER the above modest title we are presented with an important systematic and descriptive work on the Taxonomical bearing and position of the extinct Elasmobranch Fishes, and their relation to existing members of the group.

The fossil forms are numerous, and range in geological time from the deposition of the Lower Carboniferous rocks-and even earlier, assuming that certain spines, from Devonian and Silurian deposits, really belong to Elasmobranch fishes-and through all subsequent geological periods into the later Tertiaries. The geographical range is also co-extensive with that of the other subclasses of extinct fishes.

The fossil remains, with few exceptions, and these mostly of recent acquisition, consist mainly of unconnected portions of cartilage, vertebræ, bony spines (Ichthyodorulites), and teeth. This disassociation of important parts greatly puzzled the earlier naturalists in their efforts to determine the nature and connection of these fragments with each other; and also in realizing the near affinity of some of the extinct forms to existing genera. But the researches of later investigators, with far greater facilities for comparison and intercommunication, combined with the discovery in some localities of specimens more or less completely preserved, have minimized many of the difficulties encountered by the pioneers of the science. But, notwithstanding these advantages, the modern exponent still has his difficulties, as he must very often base his conclusions with regard to the genus, species, or the affinity of a fossil fish upon a mere fragment of its organism. 
In the preparation of the Catalogue, which is much more than a classified compilation of families, genera, and species, the author has studied the best works of the latest writers on the Taxonomy and Morphology of the group, whether palæontological or zoological, and with manifest advantage. He adds a few brief comments on some systems of arrangement hitherto proposed, and on a few of the various opinions regarding the affinities of certain forms. The volume also contains many valuable original descriptions, observations, and revisions of importance. The aim and scope of the work is related in the opening paragraph of the Introduction, which we reproduce. The author states: "The present volume being the first attempt at a systematic treatment of the Palæontology of the Elasmobranch fishes, it seems a fitting occasion for briefly reviewing the bearing of the newly collected evidence upon the various results that have already been attained in the study of the existing members of this great subclass. Notwithstanding its imperfections, Palreontology must necessarily be employed as the test--if it be not adopted as the basis-for all morphological and taxonomic speculations; and though the pages of the Catalogue may indicate extreme imperfection in our knowledge of the past history of most groups, there are still a few well-ascertained facts which may be already profitably dis. cussed with reference to the conclusions of recent Zoology."

"It is therefore proposed:-firstly, to enumerate the principal stages by which the most modern schemes of classification of the group have been elaborated; secondly, to summarize the known and available resources; thirdly, to recapitulate the more important palæontological results; and lastly, to discuss these results in the light of modern theories of taxonomy."

Under the heading "Taxonomic Deductions from the Study of Recent Elasmobranchs," the author gives a brief summary of the diverse classifications, and the varying terminology adopted or proposed by naturalists of repute, to distinguish the existing fishes assigned to the cartilaginous group; the following being the most important, commencing with Willughby and Ray, who "inangurated the era of modern Ichthyology in 1686." These authors " assigned to the Pisces Cartilaginei, the Lampreys, Sharks, Rays and Sturgeons." This arrangement was accepted by Artedi (1738), who made the group an "order" named Chondropterygir. It was afterwards adopted by Linnæus, who enlarged the group by the addition of other forms, "and proposed the new term of Amphibia Nastess." In 1806 Duméril, following Lacépède, who had returned to Artedi's conception of the Chondropterygii, proposed the name of Trématopnés for the fishes "possessing neither operculum nor opercular membrane," to contain two "families" which he termed Cyclostomes and Plagiostomes. "The latter group comprised the Sharks and Rays," the Chimæroids being "placed far apart." Cuvier later on added the Chimæroids to the Plagiostomes and renamed the group Selachiens. Bonaparte (1832-1841) "proposed to elevate this group into a subclass of Flasmobranchii, the two subdivisions to be regarded as orders and known respectively 
as Selacha (Sharks and Rays) and Holocephala (Chimæroids);" and the Cyclostomes to constitute a distinct subclass. Agassiz about the same time "reunited these two subclasses under an order termed Flacoidei." "In 1846 J. Müller adopted Bonaparte's subclasses, though using the term Selachii as equivalent to Elasmobranchii, and naming the two orders, Plagiostomi and Holocephali." Bonaparte's classification was also adopted in 1870 by Dr. Günther, but he termed "the subclasses Chondropterygii and Cyclostomata respectively, and the orders of the former Plagiostomata and Holocephala; while the Plagiostomes were further divided into the suborders of Selachoidei and Batoidei." But in 1871 Dr. Günther instituted his subclass PALEICHThyes, of which the Chondropterygii became an order, and Plagiostomata and Holocephala were reduced to suborders. In the same year Prof. Cope proposed to unite the Sharks and Rays in one subclass (Serachi) and the Chimæras to form another (HoLOCEPHALI) ; " this arrangement being based upon the fundamental difference in the structure of the skull already indicated in Bonaparte's second term." This classification was accepted by Prof. Huxley in 1876, but he regarded the two groups as orders, "and preferred the term Plagiostomi to that of Selachi." Our author also adopts Cope's classification, and adds, "Most modern researches have also tended to emphasize the distinction between fishes with -autostylic, and those with hyostylic skulls, both among those without membrane-bones and those possessing these skeletal elements; and such is the arrangement selected for adoption on the present occasion."

"With regard to terminology," the author observes. "the only term originally restricted to the cartilaginous hyostylic fishes is that of 'Plagiostomi,' proposed by C. Duméril; but this is both inappropriate in many instances, and also based upon a misconception of the supposed relationship existing between the Lampreys and the Sharks. We therefore venture to follow Prof. Cope in adopting Bonaparte's name, Elasmobranchii, excluding the Holocephali, and elevating these to the rank of an equivalent subclass."

Prof. Cope, in 1884, established a new order of the Elasmobranch subclass, based upon his studies of some fish remains from the Permian beds of Texas, possessing teeth of the Diplodus type, and also exhibiting "an arrangement of the mandibular and hyoid arches extremely similar to that observed in the living Notidanus." There are other supposed distinctive structural characters of the cranial elements; and upon these fossils Prof. Cope founds his genus Didymodus, to be included with Pleuracanthus and the Hybodontidæ in an order he terms Іонтн уотомг.

The necessity for forming a new order for the reception of Pleuracanthus has also recently (1888) been remarked by M. Charles Brongniart, who has been able to study numerous specimens of the genus, in fair preservation, obtained from the Middle Coalmeasures of France. The evidence thus attained enables him to attempt the restoration of the entire skeletal structure of the fish; and to suggest inclusion in a new order which he proposes to term "Pleuracanthides." 
Again, with regard to subordinal divisions. Sir Richard Owen in "Palæontology" (1860), ranks the Plagiostomi as an order, and recognizes four families: the Cestraciontidx, including the living Port Jackson Shark and the fossil forms supposed by Agassiz to be allied to it; the Hybodontidx for the extinct Hybodonts; and the Squalidæ and Raiidæ for the Sharks and Rays. Subsequently (1866), he elevated these families into suborders, the Squalidæ hecoming Selachii, the Raiidæ, Batides; and the Cestracionts and Hybodonts forming one suborder named Cestraphori, "in allusion to the presence of dorsal fin-spines."

In 1882 Prof. C. Hasse proposed as the result of his studies of the axial skeleton, a classification "based upon the varied conditions of the notochord and the vertebræ," founding thereon four groups which he named respectively: Palconotidani, in which the notochord is persistent; the Cyclospondyli, with partial calcification at intervals in the notochordal sheath, represented by the Spinacidæ; the Tectospondyli, with numerous calcified rings, comprising the modern Rays, with their near allies the Pristiophoridæ and Squatinidæ; and finally, the Asterospondyli, in which the calcification is "so arranged as to appear radiating or star-shaped in vertical transverse section." The author deems this classification one of much significance; for the various modifications of the cranium afford no "satisfactory basis for the definition of subordinal groups," and the types of axial skeleton defined by Hasse correspond nearly with the accepted divisions of the Selachii, namely, the Sharks and Rays. Thus the "Tectospondyli" comprise the Rays and their near allies, the Pristiophoridæe and Squatinidæ, while the "Asterospondyli" include the Cestraciontidæ and other Sharks. Eliminating Hasse's first two groups, the members of which "may be variously distributed" in the other two, the author, in part, accepts this classification and terminology as being in his view the best to define the subordinal divisions of the group, and which is applicable alike to the extinct and recent forms. This arrangement has the merit of being simple as well as natural.

The numerous palæontological authorities consulted in the preparntion of the Catalogue are enumerated, and the titles of their respective works annexed, forming a goodly list. The geological formations and localities whence the remains of the principal fossil groups have been derived are also briefly detailed.

The teeth and bony spines of fishes and other fossil remains have long been known, and greatly perplexed the early observers in their attempts to unravel their history. Thus, the teeth of Sharks were described as the petrified tongues of fishes, and named Glossopetroe.

An English author early in the seventeenth century ${ }^{1}$ thus quaintly describes them :- " Potters, in working their clay which is gotten in some especiall place, doe find in it certaine things which are as hard as stone, and of the very forme and shape of the tongues of some

1 Richard.Verstegan, A Restitution of Decayed Intelligence, 1605. 
sorts of fishes, each with the root unto it, to make it the very markable, and right proportion of such a kind of tongue in all respects." Their true nature was first made known by Steno in 1660, and later by Scilla in 1752, who compared them with teeth of recent Sharks. The bony spines were supposed to be jaws, and some even to be plants. That they were the dorsal fin-spines of extinct Elasmobranch fishes was first proved by Buckland and De la Beche about 1830, who proposed the term "Ichthyodorulites." “Agassiz named many of them, and assigned a few to their correct zoological position." Agassiz is also credited as being " the first to place the study of Elasmobranch Palæontology upon a truly scientific basis ;" and his great work as still forming "the groundwork of the whole subject." The researches of numerous subsequent authors on the same subject, whether of a general cbaracter or limited to a description of the fauna of a geological horizon, of a country, or a district, are respectively noticed.

In a "Synopsis of Palæontological Results," the author states that the general results of these discoveries and investigations add much that is new, and the main points of biological significance are briefly enumerated.

To give an intelligible résumé of the descriptions of the internal and external skeleton and the dentition would exceed the limits of this notice. The respective portions described are first the "Cartilage"; and this, even in the Lower Carboniferous, "exhibits a considerable amount of calcifcation." The "Head and Visceral Arches" come next, and all that is known regarding the structure of the extinct Elasmobranch skull in the various genera is fully detailed. The structure of the "Vertebral Column," and its importance as an element in the classification of the group, has been already referred to. The structural characters of the "Pectoral and Pelvic Arches and Fins," respectively, and of the "Median Fins," follow; the "Shagreen and Dermal Defences" are the next objects of comment, and finally the "Dentition."

With respect to the adoption of a classification for the extinct Sharks and Rays, the author observes, that "the first point to be considered is the validity of Prof. Cope's division of the subclass into the two orders Iонтнхотом and Selachir." The first order was fonnded upon certain modifications observed in the structure of the skull, the pectoral fins, pelvic arch, and the axial skeleton of the European Pleuracanthus and the American Didymodus; these modifications being sufficiently pronounced as to justify an ordinal separation from the other groups of the subclass. But the principal character is the structure of the pectoral fin, in which the metapterygium forms a long segmented central axis, and as this structure "differentiates the Crossopterygii from the higher Ganoidei or Actinopterygii," the same character separates the Ichthyotomithough perhaps less widely-from the Selachii. The order therefore, as here defined, is limited to those fishes that possess this type of fin. The reason for the inclusion of the Sharks and Rays in one order is explained by the difficulty of defining a distinct live of 
demarcation between the Sharks with lateral gill-clefts and the Rays with ventral gill-clefts, seeing that there are many intermediate gradations of skeletal structure, of habit, and of external form by which one group passes into the other. Some of these gradations are enumerated in the following passage:- "The Squatinidæ and Pristiophorida, for example, possess lateral gill-clefts, like Sharks; but the structure of the vertebræ, the partial growth forwards of the pectoral propterygium in Squatina, and several striking resemblances existing between Pristiophorus and Pristis and Rhinobatus, all point to the Squatinide and Pristiophoridæ as probably survivors of ancestral Rays."

For the grouping of families and genera, "the arrangement formulated by Dr. Günther in his Catalogue of 1870 for the recent forms," is adopted, and where possible the "extinct families and genera will be incorporated among them."

We have referred at some length to this subject of classification, it being an important element in the work. Although Bonaparte's classification and terminology for the whole group is adopted, Hasse's subdivisions founded upon the structure of the axial skeleton, and Cope's new order based upon other structural characters, have been added; but each, as alreaily stated, with modifications and restrictions, the result being an emphatically new classification, which appears to be, approximately, a good natural one, in our present knowledge of the fossil groups. The author modestly observes that "this Catalogue, however, can only be regarded as a provisional attempt to systematize and arrange the ascertained facts of Elastmobranch Palæontology for convenience of reference."

In the Catalogue a diagnosis of the principal distinguishing characters is attached to each order, family, genus and species respectively, with comments. The nature of the type specimen, where preserved, if known, and the formations and localities whence the various specimens have been derived, are also given. The synonyms of the genera and species, if any, also lists, with references, to all the species of each genus described, as far as ascertainable, but of which no specimens are in the Museum, are included. All these details have necessitated much labour and research, the result being a most valuable work of special reference.

The first Order, Ichthyotomi, as already mentioned, is limited to those fishes having a long segmented axis in the pectoral fins, analogous to that in the Ganoid Crossopterygians; it comprises the families Pleuracanthides and Cladodontid a. To the former are assigned the genera Pleuracanthus, Diplodus, and Chondrenchelys. We have here, on the very threshold of the Catalogue, interesting evidence of the progress of recent palæontological investigations into the nature and relationships of various imperfect fragments described by previous authors, in the merging of many genera into one. Thus to the genus Pleuracanthus, founded by Agassiz for the reception of some barbed spines from the Coal Measures, are referred no less than thirteen genera, namely, Diplodus, Orthacanthus, Xenacanthus, Triodus, Compsacanthus, Dittodus, Aganodus, Ochlodus, Pter- 
nodus, Thrinacodus, Lophacanthus, Anodontacanthus, and Didymodus. Diplodus, however, is provisionally retained for the teeth not correlated with spines.

Pleuracanthus decheni, a small species from the Lower Permian of Rhenish Prussia and elsewhere, has been long and is best known by numerous specimens in fairly complete preservation. With the exception of P. Gaudryi and P. (Didymodus) texensis, the other species are only known by teeth and the cephalic spines, the latter being placed on the head in advance of a small fin. Teeth and spines indicate that some species or individuals attained a large size. The remarkable, but imperfectly known Chondrenchelys, discovered by Dr. Traquair in the Lower Carboniferous rocks of Eskdale, is provisionally placed in this family on account of the resemblance to Pleuracanthus of the axial skeleton, the similarity of the form of the body and the presence of a long dorsal fin, but it has no cephalic spine. The Cladonontide are "an indefinable family, apparently closely allied to the Pleuracanthidæ." Dr. Traquair has discovered the pectoral fins of the type genus Cladodus, and states that they possess the characteristic structure of the order. But with this exception, all the species of the family are only known by detached teeth, no spines being assigned to the group. Six genera are noticed, three being American, but of these there are no specimens in the collection. Phobodus is a Devonian genus from Iowa. The other genera only occur in rocks of Carboniferous age.

We next come to the order Sribacuir, and the suborder Tectospondyli, comprising twelve families, the first being the SpINACIDE, and the last the Trygonider. The first family, Spinacidæ, contains fossil representatives of the existing genera Centrina, Acanthias, Centrophorus, Spinax, and Scymnus, hitherto classed with the Sharks. The fossil species of Acanthias and Centrophorus are from the Upper Cretaceons of Mount Lebanon, Syria. ${ }^{1}$

The Petalodontrdes follow next, with nine genera. "The genus Janassa affords the most complete insight into the characters of this family;" the dentition of one species (J. bituminosa) from the Permian having been found in natural apposition. The other genera being only known by detached teeth and such fragmentary portions. A new genus and species, Mesolophodus problematicus; and two species of Petalodus (P. flabellula and P. Davisii) are here first described. With the exception of the Permian Janassa bituminosa, all the other species are from Carboniferous rocks. The SQuatinidz have one genus, Squatina, and five species, two being Kimmeridgiau and three Cretaceous. One new species (S. crassidens) from Mount Lebanon is described.

To the Pristide a new genus and species (Sclerorhynchus atavus) is added, founded on an imperfect rostrum, also from Mount Lebanon.

1 From this formation and locality the Museum possesses a large series of fish and other remains, remarkable alike for the numbers of genera, species, and of individuals represented, and also the beautiful state of their preservation. The collection contains many of the types of this subclass and also of the Ganoid and Teleostean fishes, described from this locality. 
From the same locality the Museum contains four species of Rhinobatus, and the type specimens of three; the fourth ( $R$. maronita) being in the Geneva Museum. This is the only genus of the Rhinobatidæ in the collection. The $R_{A J I D A}$ is also only represented by the genus Raja. The type specimens of three species, also from the Isebanon, are in the collection, one ( $R$. primarmata) being here first described and figured. The well-known dermal tubercles from the Norwich Crag, named by Agassiz Raja antiqua, are now referred to the common Thornback ( $R$. clavata).

The PSAmmodonside, here classed with the Rays, were referred by Agassiz to the Cestraciont group. The family is extinet and only known by the dentition, and this shows "that the two rami of the jaws were evidently placed in the same straight line-a fact indicating a much depressed body, like that of existing Rays." It comprises the genera Copodus and Psammodus. The former consists of eleven species, of which all the type specimens are in the Museum; the latter of six species and some of the types. One new species ( $P$. salopiensis) is described. The species are all Carboniferous, and the best known, $P$. porosus, is now referred to $P$. rugosus.

The Mrliobatide come next with eight species of Myliobatis, all Tertiary. Only those known by the dentition are catalogued, and the published British species are reduced in number. The upper and luwer series of connected dental plates are distinguished, the upper series are arched antero-posteriorly, the lower series being flat; and the barbed spines referred to the genus are generically indeterminable. Une new species (M. (?) tumidens) from the Red Crag and also a new species of Rhinoptera (R. Daviesii) from the London Clay are described. The dental plates named Zygobatis by Agassiz were referred to this genus by Dr. Günther in 1880, Aetobatis is allied to the last-named genus, but distinguished by the absence of lateral teeth. The long familiar Cretaceous genus Ptychodus, and its many species, once prominent members of the Agassizian group of Cestracionts, is placed by the author in this family, he being the first to discover, by the arrangement of the dentition, its natural affinity to the Rays. The teeth were numerous in each mouth, and arranged in many longitudinal and transverse rows. The median antero-posterior row in one jaw is very small, the row on either side being much larger; in the other jaw the teeth of the median row are large, and those on each side smaller. Ptychodus is only known by the teeth and vertebræ. The vertebræ are "apparently 'cyclospondylic' in structure," and were found in immediate association with teeth of $P$. decurrens in a block of chalk. Many of Agassiz's types are in the collection; and there is one new species, $P$. multistriatus. The fin-spines and rays referred to this genus by Agassiz do not even belong to the same subclass. Of the Trygonides, the only genus in the collection is Cyclobatis, with two species and the type specimens of each. This ends the Tectospondylic section.

Only six families are assigned to the suborder Asterospondyli, but the genera and species are many. The Nombanide is the first family, "its relationships," according to the author, "being 
obviously closer with the Cestraciontidæ than with any other recognized family." Eight species of Notidanus-the only fossil genus known with certainty - are registered, the species ranging from the Jurassic rocks to the Red Crag inclusive.

The Cochliodontida come next-" an imperfectly definable family, apparently related to the Cestraciontidx, but with a more specialized dentition." The group is restricted to the Carboniferous period, and includes many of Agassiz's Cestraciont genera. Of the nine species of Helodus originally named by Agassiz, only one ( $H$. simplex), from the Coal-measures, remains, the others being variously distributed. We then have an innovation, a new generic name, Pleuroplax, as being more appropriate, is substituted for Pleurodus. Psephodus follows with two new species (P. salopiensis and $P$. dubius). A British species, Sandalodus Morrisii, from Oreton, appears to be the largest of the genus. In addition to the above named, the following genera are included in the family: Tomodus, Xystrodus, Deltodus, Pocilodus, Cochliodus, Streblodus, Deltoptychius, Diplacodus, and Cyrtonodus. New species of Deltodus (D. gibbus and D. rugosus), and one of Cyrtonodus (C. Hornei), are added.

The Cestraciontide as here defined form an important group of fifteen genera and about seventy species. Of these only three genera (Orodus, Strophodus, and Acrodus) originally assigned by Agassiz to the family remain. The teeth are described as being " mostly obtuse, never fused into continuous plates; several series simultaneously in function;" and "no distinctive characteristics of value having yet been discovered, the so-called ORODONTID Hybodontid a are included in the family." Its fossil representatives first appear in the Lower Carboniferous, and occur in more or less abundance in all the succeeding periods to the Chalk inclusive, the living Port Jackson Shark being the last survivor of the group. One of the earlier forms, Sphenacanthus costellatus, described by Dr. Traquair, is known by a fairly complete fish in the Museum having both dorsal spines in natural position; the other Carboniferous forms being mainly represented by detached teeth and fin spines. Hybodus is probably the most completely known genus of the family. Liassic and Wealden specimens in the collection show interesting portions of the cranial structure, the internal skeleton and the external form; also the dermal covering, the booked cepbalio spines (Sphenonchus), and the dorsal fin spines, each in their respective positions. Moreover, in its close ally Acrodus, the arrangement of the dentition is observed. Portions of nearly complete jaws of each genus with the teeth in natural apposition are figured.

The numerous Oolitic teeth named Strophodus are now practically known to belong to the Ichthyodorulites named Asteracanthus by Agassiz; Strophodus, however, being provisionally retained for the teeth not correlated with spines. The teeth named respectively S. reticulatus and S. subreticulatus have been found associated with the dorsal fin-spines of Asteracanthus ornatissimus, which name they now bear; Owen's $\boldsymbol{S}$. medius is also a synonym. The author has discovered that the species was armed with cephalic spines resembling 
those of Hybodus and Acrodus. Palcospinax (Thyellina), placed by Agassiz among the Squalidæ, now passes to this family; and some interesting specimens of the genus are described, including one new species from the Lias of Ohmden. A closely allied form is the author's Cretaceous genus Synechodus, originally referred to the genus Hybodus, and known by jaws, teeth, fragments of cartilage, vertebræ and shagreen.

T'o the genus Cestracion, the last of the group, is referred Sir Philip Egerton's genus Drepanephorus. Six new species of as many genera are described; and most of the types, either wholly or in part, are in this collection.

The Scrulide come next with seven genera. The first, Palaoscyllium, is represented by one species ( $P$. minus), a new one from the Kimmeridgian of Bavaria. Scyllinm follows with six species, all Cretaceous, two being new, $S$. dubium from the Lower Chalk, Dover, and $S$. (?) tumidens from the Lebanon. Cantioscyllium decipiens is a new genus and species, founded upon the character of the dentition, receutly exposed by the removal of the matrix on one of Agassiz's figured types (tom. iii. pl. xxxviii. fig. 2) of Scylliodus antiquus.

To the LAMNIDA are assigned eight genera, represented by forty-six species; but the teeth of the fossil genera are separated by characters so slight that it is difficult in some instances to distinguish them. Thus Odontaspis only seems to differ from Lamna in " the greater relative size and more subulate character of its anterior teeth." Oxyrhina, again, "only differing from Lamna in the prevailing absence of lateral denticles in the teeth." Again, Lamna, by Oxyrhina mantelli, "appears to be connected with Oxyrhina; and by Lamna obliqua, with Carcharodon." Orthacodus is a new generic name proposed for Agassiz's Lamna (Sphenodus) longidens, and Scapanorhynchus is another new genus founded upon several more or less perfect specimens from the Lebanon Cretaceous beds, and replaces the genus Rhinognathus of J. W. Davis; from the same locality a new species ( $S$. elongatus) is described, and a tooth (S. gigas) from the Cambridge Greensand. To the same genus are also assigned the Cretaceous teeth respectively known as Lamna (Oduntaspis) rhaphiodon and L. subulata.

'To Odontaspis are assigned the teeth universally known as Lamna elegans, also the other species of Lamna having the same general form of tooth. Otodus disappears, the species being absorbed in the genus Lantna, which is thus defined: "Dentition only differing from that of Odontaspis in the relatively less elevated and less subulate character of the anterior teeth, and the usually larger size of the lateral denticles." One new species is described. Then comes Carcharodon with five species, all of Tertiary origin. One species, $C$. megalodon, attained an enormous size, and was very widely distributed. 'The teeth referred to the genus Corax are comparatively small, compressed and serrated.

'The last family is the CARCHARImes. Of the type genus Carcharias, species of three of its five subgenera are in the collection, and there are two new species. The other genera composing the family, and represented by species, are Galeocerdo, Hemipristis, Galeus (?), and Sphyrna. 
Having briefly sketched, without criticism, some of the main points of the classification here formulated for the arrangement of the fossil Elasmobranch Fishes, we bave only to add that it is based principally on the study of the structural characters, and an intimate knowledge of the numerous remains in the collection whose arrangement forms part of Mr. Woodward's official duties; and also on the study of many specimens in private or public collections. Wherever possible, the fossils have been carefully compared with recent forms, and, as we have seen, other systems of arrangement have been studied with a view to their adoption, wholly or in part. The result is a palæontological classification, apparently the most natural and practical hitherto suggested for this group of extinct fishes. Modifications, sooner or later, will probably have to be made when more is known regarding the structure and affinities of the obscurer forms, but this cannot affect the principle on which it is based. We commend the author for its inception, and also for the industry displayed in the preparation of the Catalogue, and shall lonk with interest for the publication of the second part, which we understand will contain the Holocephali and Ichthyodorulites.

Six new genera and thirty-one new species are described, and most of them figured.

Of the 17 lithographic plates, seven are double, and the whole contain about 230 figures, while there are 15 woodcuts in the text.

The fossils have been drawn from nature by Miss G. M. Wood. ward with ber usual fidelity to form and structure, and we would specially note the beautiful rendering of the ornamentation on the teetb of Acrodus in plates xiii. and xiv.

W.D.

\section{REPORTS AIND PROCFEDINGS.}

\section{Ghological Society of London.}

I.-June 5, 1889.-Prof. J. W. Jurd, F.R.S., Vice-President, in the Chair.-The following communications were read :-

1. "Observations on some undescribed Lacustrine Deposits at Saint Cross, Southelmham, in Suffolk." By Charles Candler, Esq. Commmunicated by Clement Reid, Esq., F.G.S.

These deposits are situated in the basin of the River Waveney, $3 \frac{3}{4}$ miles E. by N. of Harleston, and 9 miles E.N.E. of Hoxne. They occupy a hollow in the Boulder-clay towards the northern edge of the plateau locally known as "High Suffolk." Saint Cross brickyard, which is the only section now visible, shows:- ft.

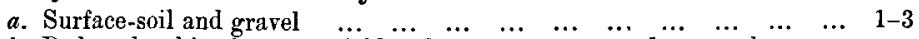

$b$. Red and white loam, variable, fine or coarse, sandy or calcareous.

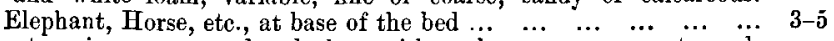

c. Fine, tenacious, grey and red clay, with carbonaceous seams towards

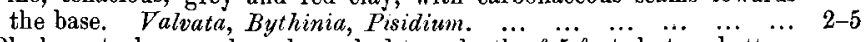

d. Black peaty loam and sand, worked to a depth of $\dddot{5}$ feet, but no bottom reached. Seeds and freshwater shells $\ldots \begin{array}{llllllll}\ldots & \ldots & \ldots & \ldots & \ldots & \ldots & \ldots & 5-\end{array}$

$\begin{array}{lllllllllll}\text { e. Chalky Boulder Clay } \ldots & \ldots & \ldots & \ldots & \ldots & \ldots & \ldots & \ldots & \ldots & \ldots & \ldots \\ \end{array}$

No implements have yet been found in any of the beds; but Pleistocene Mammalia (determined by Mr. E. T. Newton) occur in 